\title{
Kelp in IMTAs: small variations in inorganic nitrogen concentrations drive different physiological responses of Saccharina latissima
}

\author{
L. Rugiu ${ }^{1}$ (D) $\cdot$ M. S. Hargrave ${ }^{1}$ (D) $\cdot$ S. Enge ${ }^{1}$ (D) $\cdot$ M. Sterner ${ }^{2}$ (D) $\cdot$ G. M. Nylund ${ }^{1} \cdot$ H. Pavia ${ }^{1}$
}

Received: 7 July 2020 / Revised and accepted: 8 November 2020 / Published online: 29 November 2020

(C) The Author(s) 2020

\begin{abstract}
Kelps can be included in integrated multitrophic aquaculture (IMTA) where their growth and quality might benefit from the nutrient load released by other species like finfish and mussels transforming effluents from the cultured animals into valuable products. We studied how different nutrient concentrations affect growth, photosynthesis, chemical composition and pigment content of the kelp Saccharina latissima. We exposed kelps to natural seawater, water enriched to levels of ammonium and nitrate simulating finfish cage waste (IMTA1) and a combination of such enrichment with natural effluents coming from mussels (IMTA2). The algal biomass was higher and produced elevated total organic content when exposed to both IMTA1 and IMTA2. The photosynthetic responses in terms of relative electron transfer rate $\left(\mathrm{rETR}_{\max }\right)$, PSII saturation irradiance $\left(E_{\mathrm{k}}\right)$ and total nitrogen content were also positively affected by both IMTA1 and IMTA2. We found a significant enhancement in pigment content only when algae were exposed to the strongest enrichment of our study (IMTA2). Finally, we found a positive relationship between $\mathrm{rETR}_{\max }$ and growth, and the content of chlorophyll $a$ and fucoxanthin. Our results show significant physiological responses of S. latissima to nutrient enrichment mimicking IMTA settings, as well as the benefit of added nutrients through a boost in photosynthetic activity that leads to higher kelp biomass and pigment production. This study suggests that modest nitrogen enrichment such as the one in our IMTA2 setup is enough to generate not only higher kelp biomass, but also an increased biomass quality with potentially higher market value.
\end{abstract}

Keywords Aquaculture $\cdot$ Kelp $\cdot$ Phaeophyceae $\cdot$ Nutrients $\cdot$ Photosynthesis $\cdot$ Pigments $\cdot$ Bioactive compounds

\section{Introduction}

The aquaculture industry has a significant and growing role in providing food and livelihood to our society (FAO 2018). The cultivation of fed species such as finfish and crustaceans in aquaculture guarantees a predominant source of animal proteins to over one billion people globally (Pradeepkiran 2019). However, this production is often the target of concerns for the sustainability of its practice, in particular for the large amounts of nutrients into the surrounding water by intensive farming of fed species (Subasinghe et al. 2009). The quantity of dissolved nutrients released by fed aquaculture varies according to

\section{Rugiu}

luca.rugiu@gu.se

1 Department of Marine Sciences -Tjärnö Marine Laboratory, University of Gothenburg, SE 45296 Strömstad, Sweden

2 KTH Royal Institute of Technology, Teknikringen, 34 10044 Stockholm, Sweden biological factors including types of feed used, feed conversion ratio, type and biomass of species and feeding efficiency (Islam 2005). Nutrient discharge is also influenced by environmental variability due to the location such as depths, currents and seasonality (reviewed in Price et al. 2015). Excessive release of such nutrients can be responsible for eutrophication of the surrounding water, leading in some cases to planktonic blooms and hypoxia with strong ecological consequences (Ackefors and Enell 1994).

Integrated multitrophic aquaculture (IMTA) has been proposed as a possible strategy to reduce the effect of nutrient loads released from fed aquaculture (e.g. fish), whereby the waste coming from the fed species will be used as a resource by other species such as mussels and seaweeds (Chopin et al. 2001). In this way, it is possible to reduce the impact of aquaculture on the surrounding environment while increasing the efficiency of the energy and nutrient use (Troell et al. 2009). IMTA-like practices have been implemented in Asia for a long time, and in modern times the IMTA concept was developed in the USA as well as in other western countries, mostly involving seaweeds and fish (Barrington et al. 2009; Park 
et al. 2018). Seaweeds can benefit from the enrichment released by finfish farms and mostly represented by inorganic nitrogen in the forms of ammonium and nitrate produced by metabolism of amino acids (Lazzari and Baldisserotto 2008). Ahn et al. (1998) found that, on a daily basis, the nitrogen concentration next to the salmon occasionally exceeded 30 $\mu \mathrm{M}$, but its average was around $5 \mu \mathrm{M}$ in terms of ammonium and $1.7 \mu \mathrm{M}$ for nitrates. Other field observations indicate that finfish farm discharge varies according to fish activity and with the distance from the cages, ranging from 0.2-0.8 $\mu \mathrm{M}$ (Jansen et al. 2018) to $8 \mu \mathrm{M}$ higher than background concentrations (Sanderson et al. 2008). However, the values reported by these studies decrease within the first $100 \mathrm{~m}$ downstream of cages and can be diluted to background levels within $200 \mathrm{~m}$. One of the major challenges for the sustainable development of IMTA is the bioremediation of such discharges while recycling them to produce valuable biomass.

The effects of co-cultivating filtering (non-fed) mussels and seaweeds have also been explored in different parts of the world (e.g. Reid et al. 2007; Ajjabi et al. 2018). Bivalves generally affect the nutrient cycles by changing the nitrogen flux to benthic communities through their dissolved excretions and particulate biodeposits in terms of faeces and pseudofaeces, together with removing planktonic biomass and organic matter from the water column (Giles and Pilditch 2006; Cranford et al. 2007). Indeed, mussel cultures might contribute to the local dissolved inorganic nitrogen and phosphorus stocks with an additional 20 and 5\% respectively in the summer when their metabolism is higher (Jansen et al. 2011). Deploying mussel rafts between finfish cages and kelp rafts might help in preventing the accumulation of fine particulates on the latter, thus preventing reductions in kelp photosynthetic activity due to particle settlement (Reid et al. 2007). Further, Liu et al. (2004) showed that the filtering-feeding of shellfish also helps to control blooms of phytoplankton, such as diatoms, via a top-down pressure and thus indirectly affecting the competition between phytoplankton and macroalgae. Finally, when comparing monocultures of kelp and shellfish to IMTA systems with the same species, Shi et al. (2013) suggested that the multitrophic culture is the most efficient method both ecologically and economically, resulting in a higher nutrient removal from the water as well as an increased economic benefit compared to monocultures.

Saccharina latissima is the most commonly cultured kelp in Europe and North America, and it is strongly influenced by both environmental conditions and seasonality which drive variation in kelp productivity and biomass quality (i.e. Handå et al. 2013; Peteiro and Freire 2013; Marinho et al. 2015b; Vilg et al. 2015; Azevedo et al. 2016; Bruhn et al. 2016; Breton et al. 2018; Hasselström et al. 2018; Kim et al. 2019). Beside its commercial value, the cultivation of S. latissima also brings positive benefits to coastal via the removal of dissolved nutrients from the water, potentially contributing to limiting eutrophication events (Troell et al. 1999; Marinho et al. 2015a). Among the macronutrients, nitrogen is usually the limiting factor for kelp growth in the sea (Wiencke and Bischof 2012). When ammonium and nitrate are both available, laboratory experiments showed that S. latissima exhibits similar patterns of uptake for both nitrogen species (Harrison et al. 1986) and that, in the short term (4 h), simultaneous uptake of ammonium and nitrate at concentrations as high as $10 \mu \mathrm{mol} \mathrm{L}^{-1}$ and $30 \mu \mathrm{mol} \mathrm{L}^{-1}$, respectively, has been observed (Ahn et al. 1998). Due to this, S. latissima has been proposed as a good candidate for IMTA systems and an extensive amount of literature describes how IMTAs can be beneficial for both bioremediation and substantial increase in kelp biomass production (Broch et al. 2013; Rößner 2013; Fossberg et al. 2018). This kelp is an essential extractive species in IMTA designs due to its efficiency in inorganic nutrient uptake and assimilation to produce biomass and organic compounds such as proteins and pigments (Buschmann et al. 2007; Kim et al. 2017).

Photosynthetic pigments, which are a valuable group of bioactive compounds due to their antioxidant activity, are among the economically important kelp compounds. These pigments include chlorophyll $a$, carotenoids and, among them, fucoxanthin (Balboa et al. 2013). Chlorophyll $a$ is a photosynthetic pigment common to all primary producers which has been shown to possess antimutagenic and anticarcinogenic properties important in cancer prevention and neuroprotection (Negishi et al. 1997; Chernomorsky et al. 1999; Cornish et al. 2017). Carotenoids are also photosynthetic pigments, and their activity is related to photoprotection and antioxidant activity against reactive oxygen species produced as a byproduct of photosynthesis (Takaichi 2011). Carotenoids can be extracted and made available for human consumption, and when introduced into the human diet, some studies have shown that these compounds may decrease the risk of heart disease and cancer (reviewed in Holdt and Kraan 2011). Among the carotenoids, fucoxanthin is the most abundant, and can make up to $70 \%$ of the total carotenoids in brown seaweeds (Chapman 1970). Despite the increase in attention on kelp nutrient physiology (Roleda and Hurd 2019), the full extent of tissue differentiation in kelps as a result of varying nutrient availability is understudied.

Kelps such as $S$. latissima contain high levels of dietary fibres in the form of carbohydrates, the content of which changes with season (Holdt and Kraan 2011; Vilg et al. 2015). Many of the carbohydrates produced by kelps such as alginates (guluronic acid and mannuronic acid), galactose, glucose and mannose have a structural function and are situated within the cell wall (Cardozo et al. 2007; Ramnani et al. 2012; Stévant et al. 2017). These compounds are highly regarded in the food and cosmetic market to control the viscosity of products (Balboa et al. 2013). Additional carbohydrates found in the kelp cell walls, such as fucose and 
galactose, have been the target of several studies demonstrating their potential benefits for human health including antiviral, anti-tumour and anti-thrombotic activity (Wan et al. 2019). Further, other carbohydrates are produced as energystorage compounds, the most abundant of which is mannitol (Rousvoal et al. 2011). This water-soluble carbohydrate is stored in the intracellular matrix and used in food industry as sweetener as well as for the production of bioethanol through its fermentation (Hou et al. 2015).

This study aims to investigate how the cultivation of S. latissima under elevated nutrient levels, simulating the effluents from cage finfish farming, influences kelp physiology, growth and biochemistry. We also tested if the addition of blue mussels (Mytilus edulis) to this nutrient regime can result in further effects in terms of yield and tissue quality of the cocultivated kelp. If different IMTA setups stimulate a significantly higher production of economically relevant bioactive compounds, this could provide incentives for the development of kelp farming in multitrophic aquaculture.

\section{Material and methods}

\section{Sampling and algal preparation}

Seven 1-year-old Saccharina latissima sporophytes were collected on 1 of April 2019 from a commercial scale seaweed farm on the Swedish west coast $\left(58^{\circ} 51^{\prime} 19^{\prime \prime} \mathrm{N}, 11^{\circ} 01^{\prime} 40^{\prime \prime} \mathrm{E}\right)$ and were transported immersed in buckets with seawater until they reach the laboratory, within $15 \mathrm{~min}$ of the collection. The algae were kept in a flow-through system supplied with running surface seawater at the Tjärnö Marine Laboratory $\left(58^{\circ}\right.$ $\left.52^{\prime} 33.7^{\prime \prime} \mathrm{N}, 11^{\circ} 08^{\prime} 46.1^{\prime \prime} \mathrm{E}\right)$ until the start of the experiment. After the collection, thalli were gently wiped with paper tissue in order to remove visible epiphytes. Each individual kelp was split into three thallus parts following their longest axis to produce triplicates of the same alga. The samples were trimmed at the top of the blade with the aim of obtaining a similar initial wet biomass for all portion of thallus $(8.23 \pm 0.4$ $\mathrm{g}$, mean $\pm \mathrm{SD}$ ). This manipulation was verified by growth and maximum quantum yield measurements as being nondetrimental to algal growth and photosynthetic activity during a 2-week pilot experiment (data not shown). Each part of the thallus was deployed in an individual aquarium in a flowthrough system (see below, Fig. 1a and b) and allowed to acclimate for 10 days with running surface seawater (1.5 m) before starting the experiment. On 8 of April, 350 individuals of the blue mussel, Mytilus edulis, between 50 and $60 \mathrm{~mm}$ in length between umbone and shell tip were collected from hard structures adjacent to the flow-through system $\left(58^{\circ} 52^{\prime} 32.9^{\prime \prime} \mathrm{N}, 11^{\circ} 08^{\prime} 43.3^{\prime \prime} \mathrm{E}\right)$ and stored in the same lab with running seawater.

\section{Experimental setup}

A flow-through aquaria system was used to study the effect of different nutrient conditions (control, IMTA1 and IMTA2) on S. latissima (Fig. 1). We set each aquarium with one of the three different nutrient conditions. The first condition was surface seawater (control) without any manipulation, representing the natural nutrient composition in the spring in this region. The second one, IMTA1, was surface seawater enriched by pulses of ammonium nitrate $\left(\mathrm{NH}_{4} \mathrm{NO}_{3}\right)$ mimicking the dissolved inorganic nitrogen concentration within the natural range of those produced by finfish cages (Sanderson et al. 2008). The third one was the nitrogen enrichment described above (IMTA1) plus the water coming from the surface seawater enriched by blue mussel effluents (IMTA2). For the addition of inorganic nitrogen in treatment IMTA1 and IMTA2, we used a peristaltic pump to pulse a stock solution of $40 \mu \mathrm{mol}$ ammonium nitrate $\left(\mathrm{NH}_{4} \mathrm{NO}_{3}\right)$ from a $25-\mathrm{L}$ container to the aquaria. The pump was set to pulse $5 \mathrm{~mL}$ of solution in $10 \mathrm{~s}$ every $10 \mathrm{~min}$. In the present study, we did not consider urea as an additional source of nitrogen as previous studies indicate seaweed preference of ammonium and nitrate over urea (Phillips and Hurd 2003). For the IMTA2 enrichment, 50 mussels were deployed in vertical cylindrical pipes, secured and suspended in mesh bags and supplied with subsurface seawater $(1.5 \mathrm{~m})$ from the header tank at a rate of $80 \mathrm{~L} \mathrm{~h}^{-1}$. Given the size of the mussel we used, their filtration capacity was approximately $1 \mathrm{~L} \mathrm{~h}^{-1}$ each (Riisgård et al. 2014) and we included 50 for each aquarium to be sure they could filter all the incoming water. The effluent from mussel pipes was supplied directly to seaweed aquaria in conjunction with artificial nutrients. For control treatments, subsurface seawater was supplied to seaweed aquaria via empty cylindrical pipes without receiving artificial nutrients.

A water pump situated $1.5 \mathrm{~m}$ deep adjacent to the dock supplied a constant input of water to the head tank, which fed into the base of 21 cylindrical tanks containing bivalves or empty control tanks via gravity at a constant rate of $\sim 80 \mathrm{~L}$ $\mathrm{h}^{-1}$. A constant refreshment of the header tank as well as the placement of an overflow pipe $1 \mathrm{~m}$ above the outflow to the aquaria system ensured a constant flow rate throughout the experiment. Seawater flowed upwards from the base of the cylindrical tanks, through bivalve aggregations, and was supplied directly to adjacent aquaria containing S. latissima $(n=$ 21). The seaweed aquaria were situated in a large fibre glass tank which collected the effluent from seaweed aquaria before draining. The accumulation of water within this large tank, in which the seaweed aquaria were placed, ensured minimal daily temperature fluctuations. Shade cloth was placed over the entire experimental system to simulate light intensity at a depth of $2 \mathrm{~m}$, the depth at which $S$. latissima is commonly cultured. All seaweed aquaria were gently aerated to ensure water movement. Each nutrient condition was replicated in 
Fig. 1 a Schematic illustration showing the experimental setup view from above the Ecotron. The letters within the squares indicate the treatment used for each aquarium $(\mathrm{C}=$ control, $\mathrm{N}=$ IMTA1, M = IMTA2). The pictures of mussels within the vertical pipes indicated where the bivalves were located. Black dots in the bottom-left corner of some aquaria represent the position of the nine HOBOs used to record water temperature. b Picture showing the experimental system a)

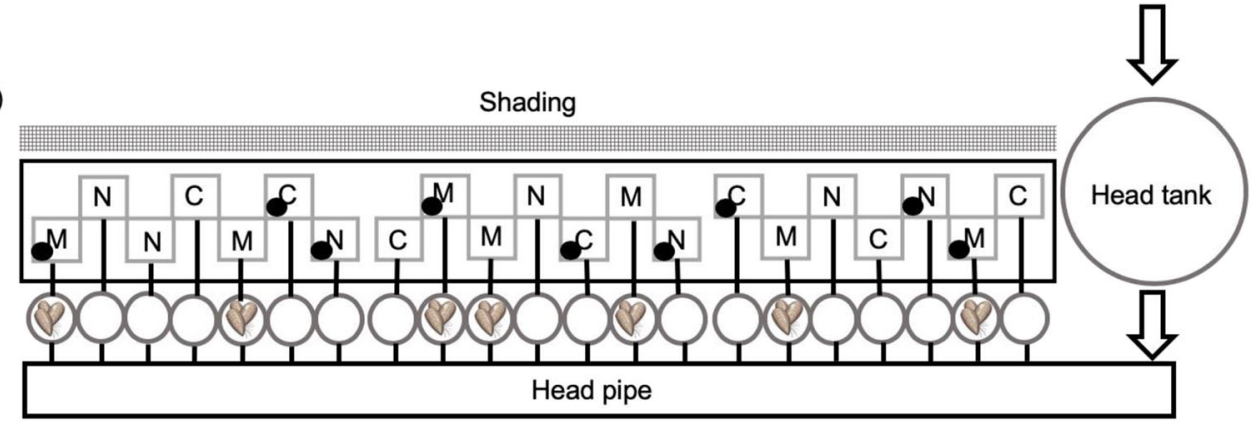

b)

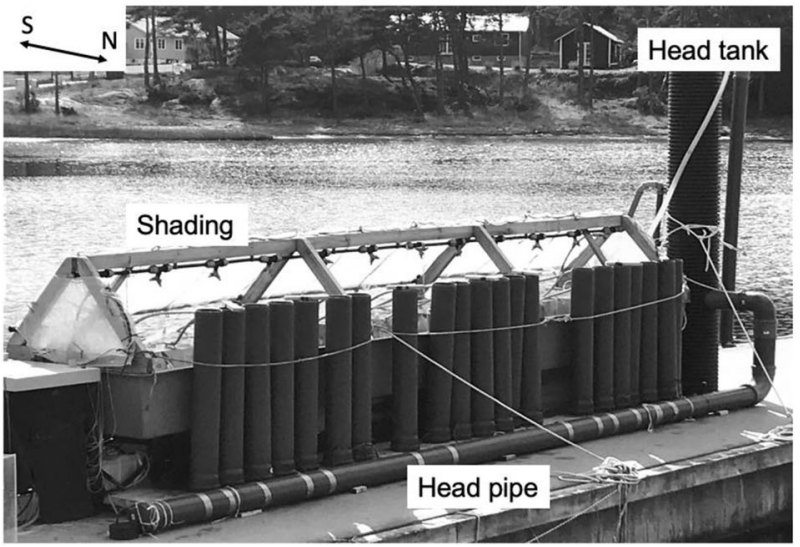

seven aquaria. Nutrient conditions were randomly assigned across aquaria, as were parts within thallus, so that each individual had one part exposed to each condition. To account for differences among thallus parts (e.g. central part vs. side 1 and/or side 2), they were also randomly assigned to each nutrient condition as shown in Fig. 1a. The experiment was run for 5 weeks starting from the 16th of April.

\section{Environmental conditions}

The experiment took place in the spring to correspond with the period in which the nutrient uptake and growth of S. latissima are the highest (Broch and Slagstad 2012; Andersen et al. 2013). One day before starting the experiment, we deployed nine HOBO Pendant Temperature Data Loggers (Onset Computer Corporation, USA) in three random aquaria for each nutrient condition (control, IMTA1 and IMTA2) to record temperature during the experiment (Fig. 1).

Before starting the experiment, we measured light irradiance with the light sensor from a Diving PAM (Walz, Germany) in the morning ( 9 am), at noon and in the afternoon (5 pm). This measurement was replicated three times on each side of the experimental system and in the centre of the aquarium tank right on the top of the aquaria. Since the algae were continuously circulating due to aeration, this allowed us to measure the maximum irradiance reaching the algae under the shading and across the aquarium tank used.

Water samples for quantification of dissolved nitrogen and phosphate were sampled weekly from each aquarium. Ten millilitres of water from each aquarium was filtered through $45-\mu \mathrm{m}$ Whatman $\mathrm{GC}$ filters and immediately stored at $-20^{\circ} \mathrm{C}$ prior to analysis. Samples were analysed using a SEAL QuAAtro analyser with XY-3 sampler (SEAL analytical, Norderstedt, Germany) for concentrations of nitrate $\left(\mathrm{NO}_{3}{ }^{-}\right)$, ammonium $\left(\mathrm{NH}_{4}{ }^{+}\right)$and phosphate $\left(\mathrm{PO}_{4}\right)$ at Kristineberg Marine Research Station.

\section{Growth responses}

Blade elongation was estimated by using a punch mark $10 \mathrm{~cm}$ above the meristem at the beginning of the experiment as reference following the method described by Parke (1948).

The relative growth rate in terms of wet biomass and elongation was derived following the formula:

Final length-initial length/duration of the experiment (days)

and expressed as elongation rate $\left(\mathrm{RGL} \mathrm{cm} \mathrm{day}{ }^{-1}\right)$ over the experimental duration.

The wet weight was measured at the end of the experiment by spinning each thallus part three times with a salad spinner and using an electric scale with \pm 0.01 accuracy. Dry weight (DW) was estimated by freeze drying each thallus part for $48 \mathrm{~h}$ and the $\%$ of dry weight expressed as:

$\% \mathrm{DW}=(\mathrm{DW} * 100) /$ final wet weight

For the ash and organic content, a portion (62-74 mg dry weight) was collected from each thallus part and then 
combusted in a furnace at $550{ }^{\circ} \mathrm{C}$ for $3 \mathrm{~h}$. When the oven temperature dropped to $300{ }^{\circ} \mathrm{C}$, the samples were cooled at room temperature inside a desiccator for at least $2 \mathrm{~h}$ before weighed to give the ash content (AW).

Then, the organic content (AFDW) calculated as:

$$
\mathrm{AFDW}=\mathrm{DW}-\mathrm{AW} \text {. }
$$

The proportion of AFDW and AW was used as conversion factor and applied to estimate the total organic content $\left(\mathrm{AFDW}_{\text {tot }}\right)$ of the full thallus parts.

\section{Photosynthetic responses}

Before assessing photosynthetic performance at the end of the experiment, algae were moved into a temperature-controlled room for a dark adaptation of $20 \mathrm{~min}$ to allow complete oxidation of PSII reaction centres before the measurements. Room temperature was set according to the water temperature directly measured from the aquaria and algae were kept inside buckets with water coming from their own aquaria. We darkacclimated the algae after 17:00 to avoid exposure to high light and possible photoinhibition. After the dark acclimation, we measured the maximum fluorescence yield (YII) using a 1$\mathrm{s}$ saturation pulse of $\sim 3000 \mu \mathrm{mol}$ photons $\cdot \mathrm{m}^{-2} \cdot \mathrm{s}^{-1}$. For the estimation of relative electron transport rate (rETR), the light levels were increased every $10 \mathrm{~s}$ and from 0 to $800 \mu \mathrm{mol}$ photons $\cdot \mathrm{m}^{-2} \cdot \mathrm{s}^{-1}$ provided by the light-emitting diode lamp of the PAM with eight pulses (Edwards and Kim 2010).

The yield of the photosystem II (YII) was measured with the following equation:

$\mathrm{YII}=\left(\mathrm{F}_{\mathrm{m}}-\mathrm{F}_{\mathrm{o}}\right) / \mathrm{F}_{\mathrm{m}}$

where $F_{\mathrm{m}}$ is the fluorescence yield reached during the saturation pulse and $F_{\mathrm{o}}$ is the fluorescence yield measured right before the saturation pulse.

The relative ETR was calculated as:

$\mathrm{rETR}=\mathrm{YII} \times \mathrm{PAR} \times 0.5$

where yield (YII) is described above, PAR stands for photon flux density of photosynthetically active radiation from the PAM halogen lamp and 0.5 is the factor to assume an equal partitioning of photons between the photosystems I and II (Genty et al. 1989).

We fitted the rETR vs. PAR curves following the model of Platt et al. (1981) with the R package "phytotools" (Silsbe et al. 2015), and we extrapolated the parameters for $\mathrm{rETR}_{\max }$, light saturation point $\left(E_{\mathrm{k}}\right)$ and the slope of the light-limited region of the light curve $(\alpha)$ from the equation.

All measurements were made on the newly grown algal tissue just above the stipe-meristem junction, where the growth occurs. Three replicates for each part of thallus were made and averaged for the calculation of each response. The rest of the thallus was covered with aluminium foil and moved to avoid photoinhibition between measurements of the same thallus part. Split algae were kept in full darkness during all measurements. We assessed the photosynthetic performance starting from the first alga on the left of the aquaria system and following the randomised order of the experimental design to avoid bias in this measurement due to time. We measured all the photosynthetic responses using the diving PAM.

\section{Analysis of chemical composition}

To estimate the nitrogen and carbon content of the algal tissue, $10 \mathrm{mg}$ samples of homogenised freeze dried material from each kelp individual were weighed into tin capsules for elemental analysis. Total carbon and nitrogen, as well as stable isotope ratios for ${ }^{15} \mathrm{~N}$ and ${ }^{13} \mathrm{C}$, were quantified with an elemental analyser (ANCA-GSL, Sercon Ltd., UK) coupled to an isotope ratio mass spectrometer (20-22, Sercon Ltd.).

For analysis of carbohydrates, freeze dried and milled algae samples were hydrolysed in order to measure individual monosaccharides. Deviations were made from the standard method (SCAN-CM 71:09) to handle lower sample volumes and more individual samples simultaneously. Volumes were decreased so that vials of $15 \mathrm{~mL}$ could be used, glass fibre filters were replaced by syringe filters and hydrolysis temperature was decreased to the expense of longer hydrolysis times. As a first step in the hydrolysis process, $25 \mathrm{mg}$ of freeze dried sample was soaked in $0.80 \mathrm{~mL} 72 \%(\mathrm{w} / \mathrm{w})$ sulfuric acid for $1.5 \mathrm{~h}$ in room temperature and in capped vials. As a second step in the procedure, $10 \mathrm{~mL}$ of deionized water was added to the sample vials, so that the sulfuric acid concentration reached approximately $9 \%(\mathrm{w} / \mathrm{w})$. As a third step, the vials were shaken at $80^{\circ} \mathrm{C}$ for $72 \mathrm{~h}$ in standing position $100 \mathrm{rpm}$ with shake radius of $1.5 \mathrm{~cm}$.

To measure eventual non-hydrolysed material, the samples were filtered through $0.2-\mu \mathrm{m}$ nylon filters that had been dried in a desiccator and weighted. The filters were cleaned by pressing through plenty of deionized water, dried in $80^{\circ} \mathrm{C}$ oven for a day, put in the same desiccator as previously and weighted again after 3 days.

The carbohydrate compositions of the hydrolysed samples were determined using a high-performance anion exchange chromatograph (Dionex, USA) equipped with a pulsed amperometric detector (HPAEC-PAD, Dionex ICS-3000) and CarboPac PA1 column $(4 \times 250 \mathrm{~mm})$, using Milli-Q water and solutions of sodium hydroxide and sodium acetate. The eluent was pumped at $1.5 \mathrm{~mL} \mathrm{~min}^{-1}$ with a program starting with $0.10 \mathrm{M}$ sodium hydroxide and increasing to $0.16 \mathrm{M}$ sodium hydroxide with $0.16 \mathrm{M}$ sodium acetate during the run. The data were processed with the Chromeleon 7.1 software. The carbohydrate standards used for calibration were mannitol and commercial alginate with a determined mannuronic/ guluronic acid composition. 


\section{Extraction of the photosynthetic pigments}

For the analysis of pigments, $5 \mathrm{~mL}$ of ethanol $/ n$-hexane (2:1) containing 0.1\% 2,6 di-tert-butyl-4-methylphenol (SigmaAldrich, Merck KGaA, Germany) as an antioxidant was added to $50 \mathrm{mg}$ freeze-dried and grounded algal material. The samples were extracted by sonication for $10 \mathrm{~min}$ and additional $50 \mathrm{~min}$ shaking in darkness at room temperature. Afterwards the samples were centrifuged, and the supernatant was evaporated to dryness under a stream of nitrogen. The extracts were then partitioned between equal volumes ( 6 $\mathrm{mL}$ ) of water and $n$-hexane. The organic phase was equally divided into two new vials and evaporated under a stream of nitrogen. One half was transferred into a 1-mL LC-vial and redissolved in $100 \mu \mathrm{L}$ acetonitrile/tert-methyl-butyl ether (7:3) for analysis by LC-DAD. The other half was re-dissolved in 90\% aqueous acetone and used for the spectrophotometric quantification of chlorophyll $a$ using the equation for brown algae by Jeffrey and Humphrey (1975) and total carotenoids using the equation of Parsons et al. (1984).

Chl $a=\left(11.47 \times A_{664}\right)-\left(0.40 \times A_{630}\right)$

Total carotenoids $=\left(7.00 \times A_{480}\right)-\left(1.49 \times A_{510}\right)$

\section{LC-DAD analysis}

The content of pigments from each sample was analysed on an Agilent Infinity 1100 Series system. Four microliters of the samples was injected onto an Agilent Poroshell EC-C18 column $(2.1 \times 150 \mathrm{~mm}, 2.7 \mu \mathrm{m})$ heated at $45^{\circ} \mathrm{C}$. A gradient of water with $0.1 \%$ formic acid (solvent $\mathrm{A}$ ) and 7:2:1 acetonitrile/methanol/tert-butyl methyl ether (solvent B) was used to separate the pigments: $0-4$ min $75 \%$ solvent $\mathrm{B}$, at $14 \mathrm{~min}$ $100 \%$ solvent $\mathrm{B}$, hold until $28 \mathrm{~min}$ at $100 \%$ solvent, at $29 \mathrm{~min} 75 \%$ solvent $\mathrm{B}$, post-run time $10 \mathrm{~min}$. The flow rate was $375 \mu \mathrm{L} \mathrm{min}^{-1}$. The pigments were quantified by DAD at $450 \mathrm{~nm}$ for carotenoids using standard curves of fucoxanthin (Sigma-Aldrich, Germany) and beta-carotene (DHI, Denmark).

\section{Statistical analysis}

We analysed the effect of exposure to different nutrient conditions on S. latissima by the use of linear models ("aov" function) within the $\mathrm{R}$ environment. We fitted the variables describing growth (RGL and organic content), photosynthetic performances $\left(\mathrm{ETR}_{\max }, E_{\mathrm{k}}\right.$ and $\alpha$ ), chemical composition (\% of dry weight of total nitrogen content, carbon to nitrogen ratio and the carbohydrates: total alginates, galactose, glucose, mannose, guluronic acid, mannuronic acid, fucose and mannitol) and bioactive compounds (chlorophyll $a$, total carotenoid, fucoxanthin) by the use of 2-factor ANOVA. We estimated the effects of nutrient conditions (factor nutrients with three levels: control, IMTA1 and IMTA2), different thallus part (factor thallus with three levels: side one, side two and the central part) and the combination of the two. The factor "thallus part" was incorporated into the model to account for possible differences in algal performances due to our manipulation (e.g. the central part had twice as much damage as the side ones). We conducted the post hoc Student-NewmanKeuls test (SNK, Keuls 1952) to compare the levels within the significant factors. We visually checked the assumption of normality and homogeneity of variance with Q/Q-plots. Further, the relationship between $\mathrm{rETR}_{\max }$ and the other traits was tested using Pearson correlation.

For the light irradiance, we used a one-way ANOVA in R to test differences among the sides and the centre of the tank to ensure similar environmental conditions to all aquaria. In this case, time measurements were pooled within position within the tank (e.g. morning, noon and afternoon for the right side vs. morning, noon and afternoon for the left side vs. morning, noon and afternoon for the centre).

We tested differences in temperature, phosphorus, ammonium and nitrate among nutrient conditions by fitting each of the abovementioned environmental factors in one-way ANOVA with nutrients as a factor within the $\mathrm{R}$ environment.

\section{Results}

\section{Environmental conditions}

The aquaria system was irradiated by $252.8 \pm 62 \mu \mathrm{mol}$ photons $\mathrm{m}^{-2} \mathrm{~s}^{-1}$ (mean $\pm \mathrm{SE}$ ) and irradiance did not differ across the system $(\mathrm{df}=2, F=0.11, p=0.9)$. The water temperature recorded throughout the experiment did not differ among nutrient conditions ( $\mathrm{df}=2, F=0.9, p=0.4)$ and was on average $12.7 \pm 0.05^{\circ} \mathrm{C}$ (Fig. 2, mean \pm SE).

Ammonium concentration differed significantly among the treatments (Fig. 2, $\mathrm{df}=2, F=61.3, p<0.001$ ). The SNK post hoc analysis indicated that the ammonium concentration was lowest in the control, higher in the IMTA1 and the highest in the IMTA2 (control vs. IMTA1: $p<0.001$; control vs. IMTA2: $p<0.001$; IMTA1 vs. IMTA2: $p<0.05$ ).

Nitrate also differed in concentration among the treatments (Fig. $2, \mathrm{df}=2, F=21.1, p<0.001$ ) as the IMTA1 and IMTA2 were both higher in nitrates than the control (control vs. IMTA1: $p<0.001$; control vs. IMTA2: $p<0.001)$ but did not differ from each other.

Phosphorus concentration also differed among treatments (Fig. 2, df $=2, F=15.6, p<0.001$ ), with higher levels in IMTA2 compared to the control and IMTA1, but no difference between the control and IMTA1 (control vs. IMTA2: $p<0.001$; IMTA1 vs. IMTA2: $p<0.001$; control vs. IMTA1: $p=0.7)$. 
O Control
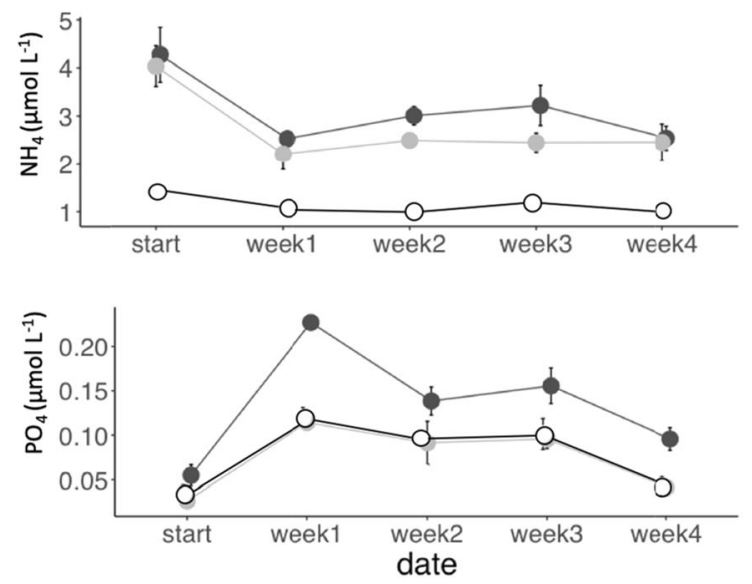

IMTA1 O IMTA2
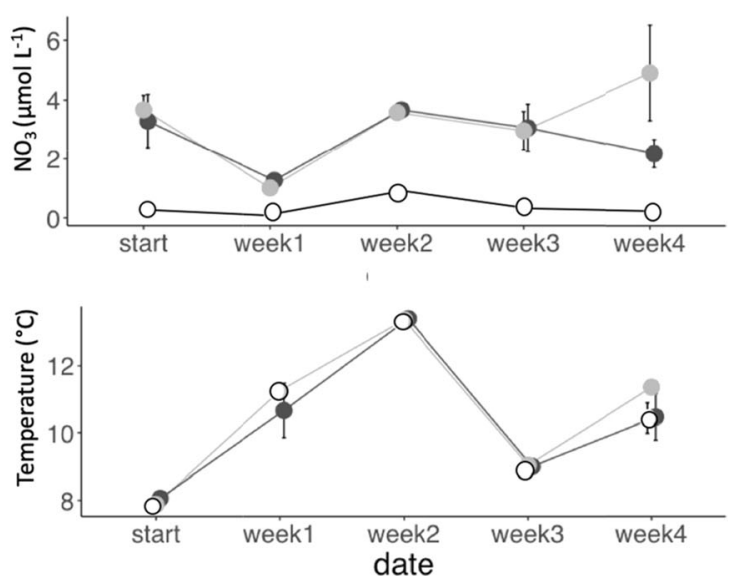

Fig. 2 Environmental parameters $\left(\mathrm{NH}_{4}, \mathrm{NO}_{3}{ }^{-}, \mathrm{PO}_{4}\right.$ and temperature) recorded every week and displayed for each water condition. Error bars indicate standard errors based on seven aquaria for each of the three levels

The seawater salinity during the experiment was $26.1 \pm 1$ PSU (mean \pm SD, https://www.weather.mi.gu.se/tjarno/data. shtml).

\section{Growth and biomass composition}

After 5 weeks, the elongation rate of S. latissima was higher when exposed to both IMTA1 and IMTA2 compared to the control seawater (Fig. 3a), and there was no difference between thallus parts (Table 1).

The algae produced a higher proportion of organic content $\left(\mathrm{AFDW}_{\text {tot }}\right)$ when exposed to both IMTA1 and IMTA2 than when exposed to control seawater (Fig. 3b, Table 1). There was no difference between IMTA1 and IMTA2, but AFDW tot differed also among thallus parts regardless the nutrient conditions (Table 1), with higher organic content in the central portion compared to the side segments (central $89.7 \pm 0.4$, side $185.3 \pm 1$, side $284.8 \pm 1$ ).

\section{Photosynthetic activity}

The photosynthetic performance of $S$. latissima was enhanced by both IMTA1 and IMTA2 as rETR $_{\max }$ and $E_{\mathrm{k}}$ were higher when compared with the algae exposed to control seawater. However, the $\mathrm{rETR}_{\max }$ and $E_{\mathrm{k}}$ did not differ between algae reared in both IMTA1 and IMTA2 (Fig. 3c-d, Table 1). All the photosynthetic traits measured were similar across thallus parts (Table 1). The slope of the light curve $(\alpha)$ did not differ across treatments nor the thallus portion (Table 1)

\section{Chemical composition}

The total nitrogen content of $S$. latissima varied according to the differences in nutrient conditions among the treatments (Table 1). We found the lowest amount of total tissue nitrogen in algae cultured in control seawater $(0.7 \pm 0.1 \%$, mean $\pm \mathrm{SE})$, while values were higher for algae exposed to IMTA1 $(1.7 \pm$ $0.5 \%$, mean $\pm \mathrm{SE})$ and IMTA2 $(2.1 \pm 0.5 \%)$. The total nitrogen content varied also among thallus parts (Table 1, with the central part storing more nitrogen regardless the nutrient conditions (thallus parts: central $1.96 \pm 0.1$, side $11.29 \pm 0.5$, side $21.31 \pm 0.59 \%)$ ).

The carbon to nitrogen ratio was also dependent on the nutrient conditions (Table 1), as both IMTA1 (20.5 \pm 2.5 , mean $\pm \mathrm{SE})$ and IMTA2 $(16.7 \pm 1.1)$ decreased this ratio compared to the control $(50 \pm 2.6)$ but did not differ from each other.

The mannitol content remained similar among the samples regardless of the nutrient conditions, and this carbohydrate made up $15 \%$ of the dry weight of the algae (Table 2). However, the content varied among thallus parts, ranging from $17.3 \pm 1 \%($ mean $\pm \mathrm{SE})$ and $15.2 \pm 1 \%$ in side 2 and 1 respectively, to $12.7 \pm 1.8 \%$ for the middle part.

Carbohydrate content did not vary significantly across nutrient conditions or thallus parts, and the mean values for each of the examined carbohydrate are displayed in Table 2.

\section{Pigment content}

All photosynthetic pigments measured showed the similar trend in concentration according to the nutrient conditions (Fig. 4a, b and c, Table 1). For chlorophyll $a$, total carotenoids and fucoxanthin, the amount of pigments found in the algal tissue was higher for IMTA2 than in control seawater, even though IMTA1 alone did not produce a significant increase.

We found a significant positive relationship between rETR $_{\max }$ and growth in terms of biomass (Fig. 5a), rETR $_{\max }$ and chlorophyll $a$ (Fig. 5b), and rETR $\max$ and total nitrogen content (Fig. 5c). Further, we found a 
Table 1 Summary of two-way ANOVA for the relative growth rate (elongation $=\mathrm{RGL}$ and organic content $=\mathrm{AFDW}_{\text {tot }}$ ), photosynthetic responses (maximum electron transport rate $=\mathrm{rETR}_{\max }$, the saturation irradiance $=E_{\mathrm{k}}$ and the slope of the light-limited region of the light curve $=$ $\alpha$ ), chemical composition (total nitrogen content $=$ Tot $\mathrm{N}$, carbon to nitrogen ratio $=\mathrm{C}: \mathrm{N}$ ) and pigment content (chlorophyll $a$, total carotenoid content and fucoxanthin)

\begin{tabular}{|c|c|c|c|c|}
\hline Factors & $\mathrm{df}$ & MS & $F$ & $p$ \\
\hline \multicolumn{5}{|l|}{ RGL } \\
\hline Nutrients & 2 & 0.02 & 4.1 & $<0.05$ \\
\hline Thallus part & 2 & 0.01 & 0.16 & 0.13 \\
\hline Nutrients $\times$ thallus part & 4 & 0.1 & 1.9 & 0.17 \\
\hline \multicolumn{5}{|l|}{ AFDW $_{\text {tot }}$} \\
\hline Nutrients & 2 & 26.9 & 8 & $<0.01$ \\
\hline Thallus part & 2 & 38.6 & 11.5 & $<0.01$ \\
\hline Nutrients $\times$ thallus part & 4 & 1.27 & 0.4 & 0.8 \\
\hline \multicolumn{5}{|l|}{$\mathrm{rETR}_{\max }$} \\
\hline Nutrients & 2 & 149.9 & 6.7 & $<0.01$ \\
\hline Thallus part & 2 & 8.5 & 0.4 & 0.7 \\
\hline Nutrients $\times$ thallus part & 4 & 4.7 & 0.2 & 0.9 \\
\hline \multicolumn{5}{|l|}{$E_{\mathrm{k}}$} \\
\hline Nutrients & 2 & 7672 & 6.3 & $<0.01$ \\
\hline Thallus part & 2 & 107 & 0.09 & 0.9 \\
\hline Nutrients $\times$ thallus part & 4 & 710 & 0.5 & 0.7 \\
\hline \multicolumn{5}{|l|}{$\alpha$} \\
\hline Nutrients & 2 & 0.07 & 3.2 & 0.07 \\
\hline Thallus part & 2 & 0.008 & 0.2 & 0.8 \\
\hline Nutrients $\times$ thallus part & 4 & 0.0007 & 1.3 & 0.3 \\
\hline \multicolumn{5}{|l|}{ Tot. $\mathrm{N}$} \\
\hline Nutrients & 2 & 3.8 & 35.9 & $<0.001$ \\
\hline Thallus part & 2 & 0.5 & 4.9 & $<0.05$ \\
\hline Nutrients $\times$ thallus part & 4 & 0.19 & 1.8 & 0.2 \\
\hline \multicolumn{5}{|l|}{$\mathrm{C}: \mathrm{N}$} \\
\hline Nutrients & 2 & 2314 & 65.8 & $<0.001$ \\
\hline Thallus part & 2 & 15 & 0.65 & 0.53 \\
\hline Nutrients $\times$ thallus part & 4 & 72 & 2.9 & 0.8 \\
\hline \multicolumn{5}{|l|}{ Chlorophyll $a$} \\
\hline Nutrients & 2 & 0.24 & 3.6 & $<0.05$ \\
\hline Thallus part & 2 & 0.01 & 0.16 & 0.8 \\
\hline Nutrients $\times$ thallus part & 4 & 0.02 & 0.3 & 0.9 \\
\hline \multicolumn{5}{|l|}{ Tot. carotenoid } \\
\hline Nutrients & 2 & 0.1 & 3.2 & $<0.05$ \\
\hline Thallus part & 2 & 0.02 & 0.5 & 0.5 \\
\hline Nutrients $\times$ thallus part & 4 & 0.06 & 0.18 & 0.9 \\
\hline \multicolumn{5}{|l|}{ Fucoxanthin } \\
\hline Nutrients & 2 & 0.07 & 3.3 & $<0.05$ \\
\hline Thallus part & 2 & 0.13 & 0.61 & 0.5 \\
\hline Nutrients $\times$ thallus part & 4 & 0.02 & 0.22 & 0.9 \\
\hline
\end{tabular}

tendency for a positive correlation between $\mathrm{rETR}_{\max }$ and fucoxanthin $(R=0.4, p=0.06)$.

\section{Discussion}

In this study, we compared the performances of S. latissima exposed to natural seawater, seawater enriched with ammonium nitrate to simulate finfish cage effluents (IMTA1) and enriched seawater with the addition of mussel effluents (IMTA2). At the end of the study, algal growth rate in terms of elongation was higher in IMTA1 and IMTA2 compared to the control seawater. Both IMTA1 and IMTA2 had a positive effect also on the organic content, total nitrogen content and carbon to nitrogen ratio, indicating a higher productivity of organic component and, in particular, proteins resulting from these nutrient conditions.

Our results indicate an overall higher growth rate of S. latissima resulting from nitrogen enrichment similar to that from cage finfish farms, in agreement with previous studies describing the benefits of culturing this species close to finfish cages (e.g. Sanderson et al. 2012; Handå et al. 2013; Reid et al. 2013). The nutrient load released by finfish cages exceeds the saturation of uptake for S. latissima $\left(10 \mu \mathrm{mol} \mathrm{L}{ }^{-1}\right.$, Ahn et al. 1998) only few metres from the farm (Jansen et al. 2018) where, due to logistic reason such as working space needed for boats, it is not reasonable to culture seaweeds. Instead, over $100 \mathrm{~m}$ away from the finfish cages, the nitrogen load released by the fish is greatly diluted to $1-2.9 \mu \mathrm{mol} \mathrm{L}{ }^{-1}$ (Jansen et al. 2018). Thus, the ammonium nitrate concentration used in the present study corresponded to nutrient concentrations in the water at a distance from finfish farms where it is feasible to cultivate kelp. Our data confirms that S. latissima can adjust its uptake and efficiently use to the excess inorganic nitrogen in a long-term exposure, making this species a good candidate for reducing the amount of inorganic nitrogen load in an IMTA system.

The photosynthetic activity of seaweeds is known to vary according to several environmental variables such as temperature, light and inorganic carbon availability (Hurd et al. 2014), but there is limited research on the influence of inorganic nitrogen availability on photosynthetic activity. In the present study, S. latissima was able to adjust its physiology to a long-term exposure to nitrogen enrichments (both IMTA1 and IMTA2) by enhancing the photosynthetic efficiency in terms of $\mathrm{rETR}_{\max }$ and $E_{\mathrm{k}}$. Higher values of $\mathrm{rETR}_{\max }$ also corresponded to higher values of growth and production of chlorophyll $a$ and fucoxanthin. However, the responses in terms of the slope of the light-limited region of the light curve $(\alpha)$ were not affected by the different nutrient conditions. In a previous study, Cabello-Pasini et al. (2011) showed that the green seaweed Ulva rigida increases its $\mathrm{ETR}_{\max }$ as well as nitrate reductase and respiration in response to nitrate concentrations up to $50 \mu \mathrm{mol} \mathrm{L}{ }^{-1}$. As Chow et al. (2013) showed for the red seaweed Gracilaria chilensis, nitrate reductase activity is directly dependent on the energy coming from the photosystems. By controlling the electron flux, seaweeds are able to 
Fig. 3 Relative growth rate (a Elongation. b Proportions of organic content) and photosynthetic activity (c $\mathrm{rETR}_{\max } \cdot \mathbf{d} E_{\mathrm{k}}$ ) of $S$. latissima at the end of the experiment. All responses are based on all the samples $(n=7)$ and represent the mean with related standard errors. The water conditions are displayed on the $x$-axis. Numbers above the bars denote significant differences according to the Student-Newman-Keuls test $(\alpha=$ $0.05)$
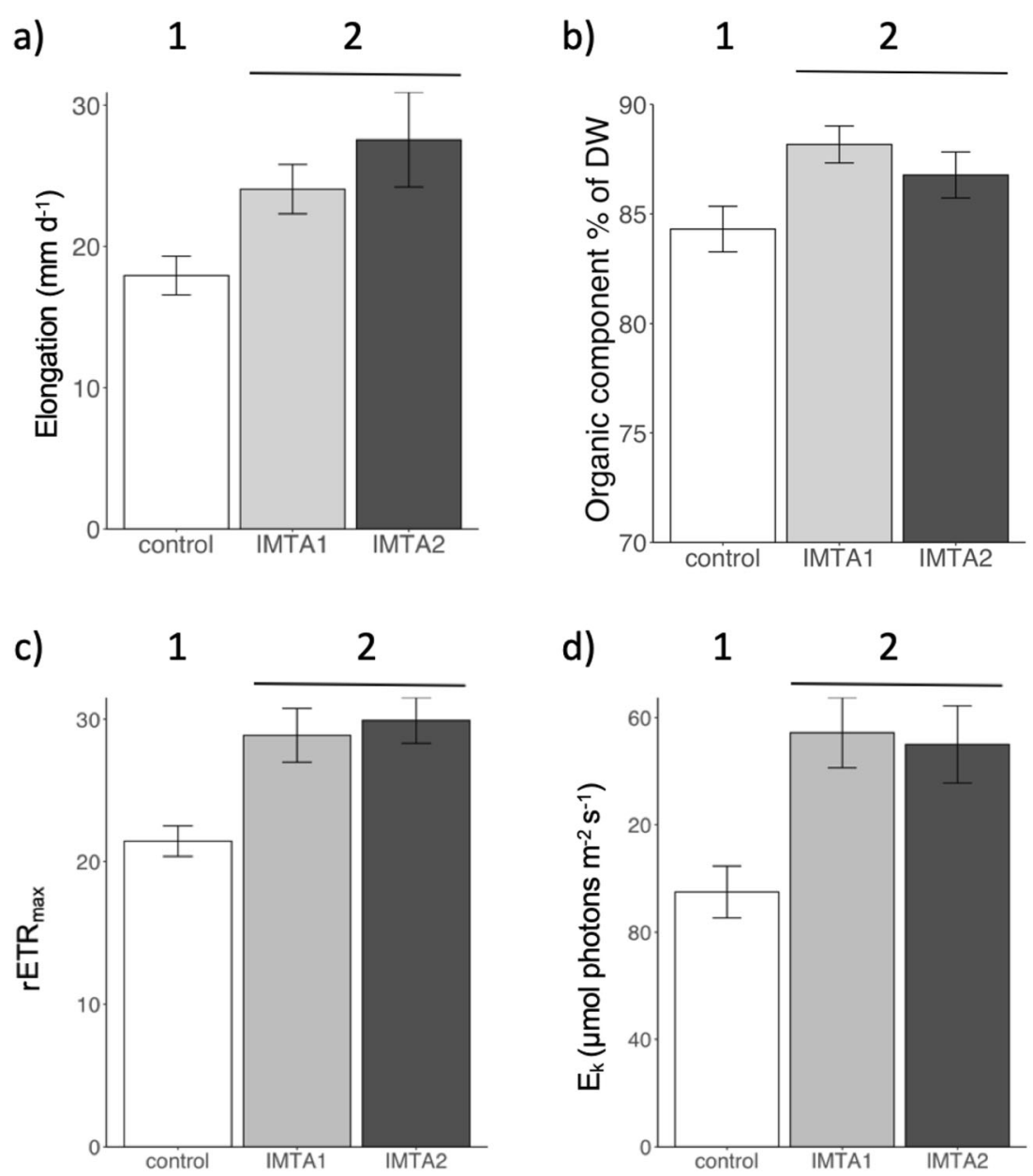

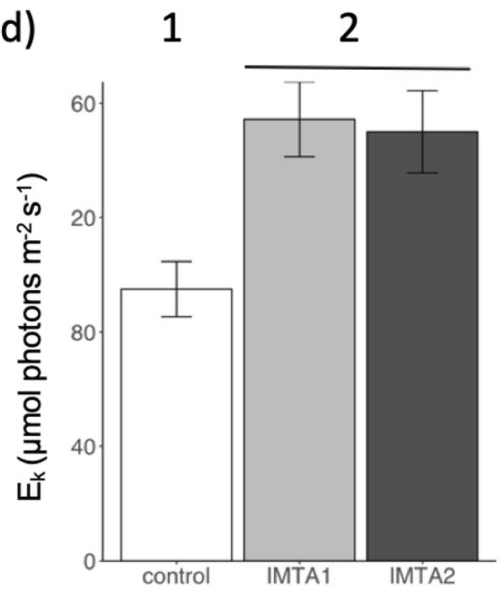

manage the assimilation of nitrogen and its incorporation into organic compounds to limit the accumulation of extra metabolites such as reactive oxygen species, which may damage the cells. Such responses can be relatively fast, and for Pyropia (Porphyra) yezoensis, $24 \mathrm{~h}$ exposure to $70 \mu \mathrm{mol} \mathrm{L}-1$ of ammonium are enough to stimulate an increase in electron transport rate and maximum quantum yield (Kang et al. 2009). Previous field experiments have tested the effects of nitrogen enrichment on the photosynthetic activity of seaweeds by comparing performances of thalli cultured near salmon farms compared to those grown far away. Among those studies, the higher nitrogen availability provided by the salmon farm enhanced the $\mathrm{ETR}_{\max }$ of $G$. chilensis (Abreu et al. 2009), while cultivating Asparagopsis armata under low nitrogen concentration decreased the seaweed's maximum quantum yield (Mata et al. 2006). For $S$. latissima cultured in outdoor tanks with different light irradiances, high nutrient enrichment ( $50 \mu \mathrm{mol} \mathrm{L}{ }^{-1}$ nitrate) had a strong positive effect on ETR $_{\max }$ regardless of the amount of light availability (Davison et al. 2007). Our results, in agreement with previous findings, indicate that there is a strong relationship between photosynthesis and inorganic nitrogen availability. Additionally, our study shows that a modest nutrient enrichment is enough to increase the electron transport rate of S. latissima.

Both nutrient enrichments (IMTA1 and IMTA2) produced algae with higher nitrogen content and lower carbon to nitrogen ratio, indicating that $S$. latissima was able to adjust uptake and assimilation of the ammonium and possibly nitrates to produce and store more proteins. The amount of nitrogen and carbon present in S. latissima varies as a function of the elemental availability in the environment (Nielsen et al. 2014; Marinho et al. 2015a). This pattern reflects the life strategy of kelps, taking up and storing nitrogen in form of proteins, pigments, free amino acids or inorganic nutrients under high ambient concentrations (Boderskov et al. 2016).

Carbohydrates are a source of energy resulting from the photosynthetic activity, which produces these compounds by assimilating carbon and light (Turpin 1991). In our experiment, it is possible that the enhanced photosynthetic activity in terms of $\mathrm{rETR}_{\max }$ and $E_{\mathrm{k}}$ found in both nutrient enrichments produced enough carbohydrates to counteract the higher energy need required to sustain growth, thus maintaining a constant concentration of mannitol and other carbohydrates used for energy storage despite the usage. 
Table 2 The summary of statistical analysis and the average carbohydrate content of S. latissima. Values of $\%$ dry weight refer to means ( \pm standard error) based on all 21 samples

\begin{tabular}{|c|c|c|c|c|c|}
\hline & df & MS & $F$ & $p$ & $\%$ of dry weight \\
\hline \multicolumn{6}{|l|}{ Mannitol } \\
\hline Nutrients & 2 & 0.07 & 0.01 & 0.9 & $14.5 \pm 1.6$ \\
\hline Thallus part & 2 & 38.7 & 5.3 & $<0.05$ & \\
\hline Nutrients $\times$ thallus part & 4 & 5.8 & 0.8 & 0.5 & \\
\hline \multicolumn{6}{|l|}{ Total alginates } \\
\hline Nutrients & 2 & 3.5 & 0.34 & 0.7 & $22.2 \pm 0.02$ \\
\hline Thallus part & 2 & 17.8 & 1.79 & 0.21 & \\
\hline Nutrients $\times$ thallus part & 4 & 14.8 & 1.49 & 0.26 & \\
\hline \multicolumn{6}{|l|}{ Galactose } \\
\hline Nutrients & 2 & 0.01 & 2.4 & 0.13 & $0.46 \pm 0.02$ \\
\hline Thallus part & 2 & 0.007 & 0.9 & 0.4 & \\
\hline Nutrients $\times$ thallus part & 4 & 0.001 & 0.12 & 0.9 & \\
\hline \multicolumn{6}{|l|}{ Glucose } \\
\hline Nutrients & 2 & 160.2 & 1.14 & 0.35 & $28.4 \pm 4$ \\
\hline Thallus part & 2 & 243 & 1.74 & 0.18 & \\
\hline Nutrients $\times$ thallus part & 4 & 104.9 & 0.75 & 0.57 & \\
\hline \multicolumn{6}{|l|}{ Mannose } \\
\hline Nutrients & 2 & 82.3 & 0.85 & 0.4 & $0.5 \pm 0.001$ \\
\hline Thallus part & 2 & 61 & 0.63 & 0.5 & \\
\hline Nutrients $\times$ thallus part & 4 & 51.4 & 0.53 & 0.7 & \\
\hline \multicolumn{6}{|l|}{ Guluronic acid } \\
\hline Nutrients & 2 & 17.6 & 1.8 & 0.2 & $10.55 \pm 1$ \\
\hline Thallus part & 2 & 4.8 & 0.5 & 0.61 & \\
\hline Nutrients $\times$ thallus part & 4 & 2.4 & 0.2 & 0.9 & \\
\hline \multicolumn{6}{|l|}{ Mannuronic acid } \\
\hline Nutrients & 2 & 3.4 & 0.16 & 0.8 & $11.73 \pm 1$ \\
\hline Thallus part & 2 & 2.9 & 1.4 & 0.28 & \\
\hline Nutrients $\times$ thallus part & 4 & 1.7 & 0.8 & 0.5 & \\
\hline \multicolumn{6}{|l|}{ Fucose } \\
\hline Nutrients & 2 & 11.4 & 1.3 & 0.3 & $1.3 \pm 0.3$ \\
\hline Thallus part & 2 & 2.7 & 0.32 & 0.7 & \\
\hline Nutrients $\times$ thallus part & 4 & 1.9 & 0.22 & 0.9 & \\
\hline
\end{tabular}

The present study shows that nitrogen enrichment has a significant influence on the photosynthetic pigments of S. latissima, thus improving its potential for the production of valuable, bioactive compounds. The enrichment generated by mussel effluent under the IMTA2 treatment positively affected the final content of chlorophyll $a$, total carotenoids and fucoxanthin after 5 weeks. The photosynthetic pigments of many seaweeds can be strongly dependent on the macronutrient availability (Friedlander and Dawes 1985; Friedlander et al. 1991; Barr and Rees 2003; Korbee et al. 2005; Barufi et al. 2011), but most of previous studies explored the effect of very high levels of nutrient enrichment. For instance, Davison et al. (2007) showed that $S$. latissima produced higher levels of chlorophyll $a$ and fucoxanthin when exposed to nitrate

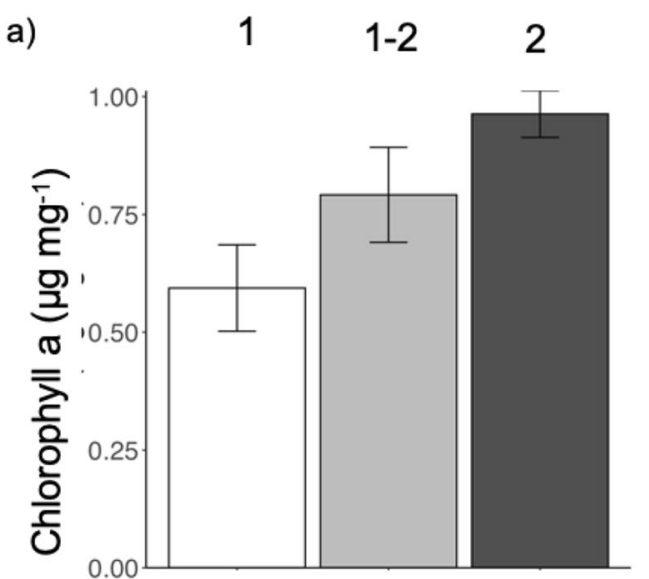

b)

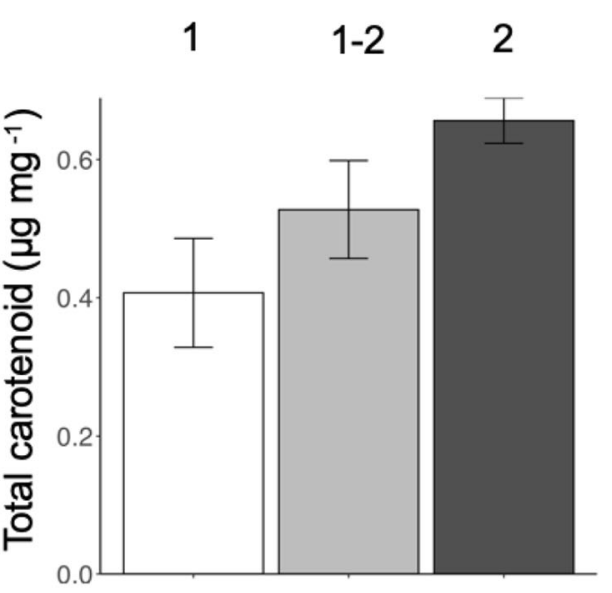

c)

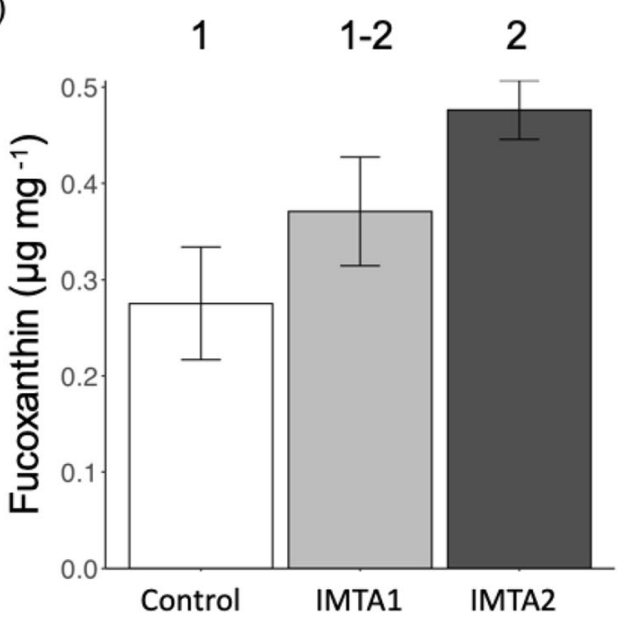

Fig. 4 Pigment content (a Chlorophyll $a$. b Total carotenoids. c Fucoxanthin) found in S. latissima at the end of the experimental period. All responses are based on all the samples $(n=7)$ and represent the mean with related standard errors. The treatment levels are displayed on the $x$-axis. Numbers above the bars denote significant differences according to the Student-Newman-Keuls test $(\alpha=0.05)$

concentrations as high as $50 \mu \mathrm{mol} \mathrm{L}{ }^{-1}$. Similarly, a simultaneous enrichment with nitrate $\left(17.98 \mu \mathrm{mol} \mathrm{L}^{-1}\right)$ and ammonium $\left(1.64 \mu \mathrm{mol} \mathrm{L}^{-1}\right)$ led to an increase in pigment content in S. latissima, with a higher content in the basal part of the 
- Control

$\Delta$ IMTA1

IMTA2
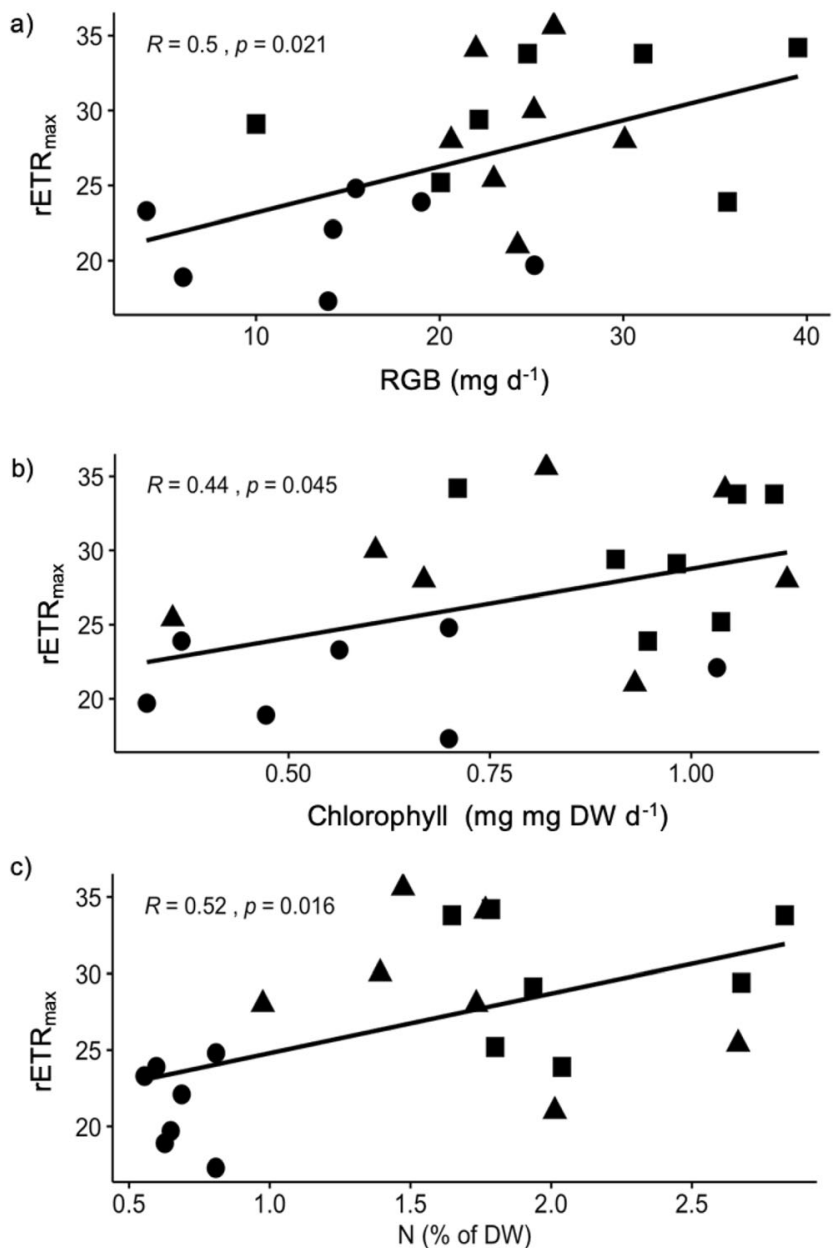

Fig. 5 Relationship between a $\mathrm{rETR}_{\max }$ and relative growth in terms of biomass (RGB), b rETR $_{\max }$ and chlorophyll $a$ and $\mathbf{c} \mathrm{rETR}_{\max }$ and nitrogen content $(\% \mathrm{~N})$. Data are displayed by water conditions according to the legend. Data from the Pearson correlation are displayed on the left of each subfigure

thallus (Boderskov et al. 2016). Together with nitrogen, inorganic phosphorus as $\mathrm{PO}_{4}{ }^{3-}$ and $\mathrm{H}_{2} \mathrm{PO}_{4}{ }^{-}$enrichment is also beneficial for algae, since it is crucial for the translation of DNA into RNA and thus relevant for protein synthesis (Sterner and Elser 2002). Further, phosphorus plays a major role in energy transmission by forming ATP. However, phosphorus addition had no effects on photosynthesis and pigments of Chondrus crispus, while nitrogen addition did, indicating on one hand that phosphorus limitations are rare, and on the other that nitrogen plays a bigger role in pigment production (Chopin et al. 1995). Accordingly, S. latissima has been observed to grow in phosphorus-depleted water for at least 2 weeks due to an internal phosphate storage in cell vacuoles (Lubsch and Timmermans 2019). In our study, we found that a small difference in ammonium and phosphorus enrichment between IMTA1 and IMTA2 resulted in a higher pigment content.
Regardless of the nutrient conditions, we found higher concentration of organic compounds and mannitol at the sides of the S. latissima thallus compared to the centre. In contrast, the total nitrogen content was higher in the central section of the thallus, indicating a higher concentration of compounds such as peptides, amino acids and proteins. This result could be due to the inborn constitutional and functional differences in tissues across the thallus. Previous studies have demonstrated that different parts of kelp thallus vary in their physiological performance. For example, Wang et al. (2013) found that carbon to nitrogen ratio as well as the photosynthetic performances varies from the basal to the upper part of the thallus of Saccharina japonica. For Laminaria digitata, iodine distribution varies within thallus and can possibly be translocated to other parts if necessary for chemical defence and antioxidative activities (Verhaeghe et al. 2008). Such variation in the chemical content can be relevant from a cultivation perspective and open the possibility to consider the use of different thallus parts for specific applications.

Here we show that kelp grown in realistic level of nitrogen elevation caused by fish cages (IMTA1) increases in growth rate and photosynthetic traits, and that the modest extra nutrient enrichment generated by the addition of mussels to this system does not lead to further effects on these traits. Despite that the bivalves in our system provided a realistic IMTA level ammonium enhancement $\left(\sim 2 \mu \mathrm{mol} \mathrm{L}{ }^{-1}\right)$, it appears that the treatment simulating nitrogen release from fish cages (3$4 \mu \mathrm{mol} \mathrm{L}{ }^{-1}$ ) fulfilled the requirements for growth becoming non-nitrogen limited. Similarly, photosynthetic parameters such as quantum yield, ETR $\mathrm{max}_{\max }$ and $E_{\mathrm{k}}$ were not seen to vary between the two IMTA treatments implying that despite a significant nutrient production by bivalves, levels required for optimal photosynthetic efficiency with regard to nitrogen limitation were already surpassed in treatment simulating nitrogen release from fish cages. The elevation of pigment content due to the mussels in IMTA2 in comparison to IMTA1 over controls suggests a continued bioremediative effect of kelp in a nutrient replete system with the additive nutrient enhancement of mussels. The increase in chlorophyll $a$, carotenoids and fucoxanthin was only detected between control levels and IMTA2 treatment, rather than from the finfish enrichment (IMTA1) alone. This suggests that while growth and photosynthetic activity cease to become nitrogen limited under simulated finfish farming conditions, the surplus ammonium produced by the mussels is still utilised by the alga. This modest surplus appears to be invested in photosynthetic pigments without directly influencing photosynthetic efficiency at the light irradiances used in this study.

Saccharina latissima is one of the most important kelps for aquaculture due to its high growth rate and high bioremediation capability. This kelp is highly suitable for IMTA systems where it has the opportunity to take advantage of the DIN released by finfish and shellfish. The present study suggests 
that such difference in DIN availability allows this kelp to produce significantly higher levels of photosynthetic pigments, which are economically relevant bioactive compounds. These findings contribute to the knowledge on how to optimise multitrophic aquaculture systems in order to maximise the ecological and economic output.

Acknowledgements Open access funding provided by University of Gothenburg. We are thankful to Annelous Oerbekke, Joel White and Gunnar Cervin for the support in setting up the experiment, Hans Olsson for taking care in analysing the water nutrients and Elena Fernández Carmona for the valuable assistance during the experiment. We are also grateful to Tjärnö Marine Laboratory for use of facility and logistical help. This work was associated with the Swedish Mariculture Research Center (SWEMARC), Center for Sea and Society, University of Gothenburg.

Funding This study was funded by SWEMARC Swedish Mariculture Research Centre (SWEMARC), Centre for Sea and Society, University of Gothenburg.

Data availability Data are available under kind request to the authors.

\section{Compliance with ethical standards}

Conflict of interest The authors declare they have no conflict of interest.

Open Access This article is licensed under a Creative Commons Attribution 4.0 International License, which permits use, sharing, adaptation, distribution and reproduction in any medium or format, as long as you give appropriate credit to the original author(s) and the source, provide a link to the Creative Commons licence, and indicate if changes were made. The images or other third party material in this article are included in the article's Creative Commons licence, unless indicated otherwise in a credit line to the material. If material is not included in the article's Creative Commons licence and your intended use is not permitted by statutory regulation or exceeds the permitted use, you will need to obtain permission directly from the copyright holder. To view a copy of this licence, visit http://creativecommons.org/licenses/by/4.0/.

\section{References}

Abreu MH, Varela DA, Henríquez L et al (2009) Traditional vs. integrated multi-trophic aquaculture of Gracilaria chilensis C. J. Bird, J. McLachlan \& E. C. Oliveira: Productivity and physiological performance. Aquaculture 293:211-220

Ackefors H, Enell M (1994) The release of nutrients and organic matter from aquaculture systems in Nordic countries. J Appl Ichthyol 10: 225-241

Ahn O, Petrell RJ, Harrison PJ (1998) Ammonium and nitrate uptake by Laminaria saccharina and Nereocystis luetkeana originating from a salmon sea cage farm. J Appl Phycol 10:333-340

Ajjabi LC, Abaab M, Segni R (2018) The red macroalga Gracilaria verrucosa in co-culture with the Mediterranean mussels Mytilus galloprovincialis: productivity and nutrient removal performance. Aquac Int 26:253-266

Andersen GS, Pedersen MF, Nielsen SL (2013) Temperature acclimation and heat tolerance of photosynthesis in Norwegian Saccharina larissima (Laminariales, Phaeophyceae). J Phycol 49:689-700
Azevedo IC, Marinho GS, Silva DM, Sousa-Pinto I (2016) Pilot scale land-based cultivation of Saccharina latissima Linnaeus at southern European climate conditions: growth and nutrient uptake at high temperatures. Aquaculture 459:166-172

Balboa EM, Conde E, Moure A, Falque E, Dominguez H (2013) In vitro antioxidant properties of crude extracts and compounds from brown algae. Food Chem 138:1764-1785

Barr NG, Rees TAV (2003) Nitrogen status and metabolism in the green seaweed Enteromorpha intestinalis: an examination of three natural populations. Mar Ecol Prog Ser 249:133-144

Barrington K, Chopin T, Robinson S (2009) Integrated multi-trophic aquaculture (IMTA) in marine temperate waters. Integrated multitrophic aquaculture (IMTA) in marine temperate waters. In: Soto D (ed) Integrated mariculture: a global review. FAO Fisheries and Aquaculture Technical Paper. No. 529. Rome, FAO, pp 7-46

Barufi JB, Korbee N, Oliveira MC, Figueroa FL (2011) Effects of N supply on the accumulation of photosynthetic pigments and photoprotectors in Gracilaria tenuistipitata (Rhodophyta) cultured under UV radiation. J Appl Phycol 23:457-466

Breton TS, Nettleton JC, O'Connell B, Bertocci M (2018) Fine-scale population genetic structure of sugar kelp, (Laminariales, Phaeophyceae), in eastern Maine, USA. Phycologia 57 (1):32-40

Boderskov T, Schmedes PS, Bruhn A, Rasmussen MB, Nielsen MM, Pedersen MF (2016) The effect of light and nutrient availability on growth, nitrogen, and pigment contents of Saccharina latissima (Phaeophyceae) grown in outdoor tanks, under natural variation of sunlight and temperature, during autumn and early winter in Denmark. J Appl Phycol 28:1153-1165

Broch OJ, Slagstad D (2012) Modelling seasonal growth and composition of the kelp Saccharina latissima. J Appl Phycol 24:759-776

Broch OJ, Ellingsen IH, Forbord S, Wang X, Volent Z, Alver MO, Hand A, Andresen K, Slagstad D, Reitan KI, Olsen Y, Skjermo J (2013) Modelling the cultivation and bioremediation potential of the kelp Saccharina latissima in close proximity to an exposed salmon farm in Norway. Aquac Environ Interact 4:187-206

Bruhn A, Tørring DB, Thomsen M, Canal-Vergés P, Nielsen MM, Rasmussen MB, Eybye KL, Larsen MM, Balsby TJS, Petersen JK (2016) Impact of environmental conditions on biomass yield, quality, and bio-mitigation capacity of Saccharina latissima. Aquac Environ Interact 8:619-636

Buschmann AH, Varela DA, Hernandez-Gonzalez MC, Huovinen P (2007) Opportunities and challenges for the development of an integrated seaweed-based aquaculture activity in Chile: determining the physiological capabilities of Macrocystis and Gracilaria as biofilters. J Appl Phycol 20:121-127

Cabello-Pasini A, Macías-Carranza V, Abdala R, Korbee N, Figueroa FL (2011) Effect of nitrate concentration and UVR on photosynthesis, respiration, nitrate reductase activity, and phenolic compounds in Ulva rigida (Chlorophyta). J Appl Phycol 23:363-369

Cardozo KHM, Guaratini T, Barros MP, Falcão VR, Tonon AP, Lopes NP, Campos S, Torres MA, Souza AO, Colepicolo P, Pinto E (2007) Metabolites from algae with economical impact. Comp Biochem Physiol C 146:60-78

Chapman VJ (1970) Seaweeds and their uses. Methuen, London

Chernomorsky S, Segelman A, Poretz RD (1999) Effect of dietary chlorophyll derivatives on mutagenesis and tumor cell growth. Teratog Carcinog Mutagen 19:313-322

Chopin T, Gallant T, Davison I (1995) Phosphorus and nitrogen nutrition in Chondrus crispus (Rhodophyta): effects on total phosphorus and nitrogen content, carrageenan production, and photosynthetic pigments and metabolism. J Phycol 31:283-293

Chopin T, Buschmann AH, Halling C, Troell M, Kautsky N, Neori A, Kraemer GP, Zertuche-González JA, Yarish C, Neefus C (2001) Integrating seaweeds into marine aquaculture systems: a key toward sustainability. J Phycol 37:975-986 
Chow F, Pedersén M, Oliveira MC (2013) Modulation of nitrate reductase activity by photosynthetic electron transport chain and nitric oxide balance in the red macroalga Gracilaria chilensis (Gracilariales, Rhodophyta). J Appl Phycol 25:1847-1853

Cornish ML, Critchley AT, Mouritsen OG (2017) Consumption of seaweeds and the human brain. J Appl Phycol 29:2377-2398

Cranford PJ, Strain PM, Dowd M, Hargrave BT, Grant J, Archambault M (2007) Influence of mussel aquaculture on nitrogen dynamics in a nutrient enriched coastal embayment. Mar Ecol Prog Ser 347:61-78

Davison IR, Jordan TL, Fegley JC, Grobe CW (2007) Response of Laminaria saccharina (Phaeophyta) growth and photosynthesis to simultaneous ultraviolet radiation and nitrogen limitation. J Phycol 43:636-646

Edwards MS, Kim KY (2010) Diurnal variation in relative photosynthetic performance in giant kelp Macrocystis pyrifera (Phaeophyceae, Laminariales) at different depths as estimated using PAM fluorometry. Aquat Bot 92:119-128

FAO (2018) The state of world fisheries and aquaculture. Food and Agriculture Organization of the United Nations, Rome

Fossberg J, Forbord S, Broch OJ, Malzahn AM, Jansen H, Handå A, Førde H, Bergvik M, Fleddum AL, Skjermo J, Olsen Y (2018) The potential for upscaling kelp (Saccharina latissima) cultivation in salmon-driven Integrated Multi-Trophic Aquaculture (IMTA). Front Mar Sci 5:418

Friedlander M, Dawes CJ (1985) In situ uptake kinetics of ammonium and phosphate and chemical composition of the red seaweed Gracilaria tikvahiae. J Phycol 21:448-453

Friedlander M, Krom MD, Ben-Amotz A (1991) The effect of light and ammonium on growth, epiphytes and chemical constituents of Gracilaria conferta in outdoor cultures. Bot Mar 34:161-166

Genty B, Briantais JM, Baker NR (1989) The relationship between the quantum yield of photosynthetic electron transport and quenching of chlorophyll fluorescence. Biochim Biophys Acta, Gen Subj 990:87_ 92

Giles H, Pilditch CA (2006) Effects of mussel (Perna canaliculus) biodeposit decomposition on benthic respiration and nutrient fluxes. Mar Biol 150:261-271

Handå A, Forbord S, Wang X, Broch OJ, Dahle SW, Størseth TR, Reitan KI, Olsen Y, Skjermo J (2013) Seasonal- and depth-dependent growth of cultivated kelp (Saccharina latissima) in close proximity to salmon (Salmo salar) aquaculture in Norway. Aquaculture 414 415:191-201

Harrison PJ, Druehl LD, Lloyd KE, Thompson PA (1986) Nitrogen uptake kinetics in three year-classes of Laminaria groenlandica (Laminariales: Phaeophyta). Mar Biol 93:29-35

Hasselström L, Visch W, Gröndahl F, Nylund GM, Pavia K (2018) The impact of seaweed cultivation on ecosystem services-a case study from the west coast of Sweden. Mar Pollut Bull 133:53-64

Holdt SL, Kraan S (2011) Bioactive compounds in seaweed: functional food applications and legislation. J Appl Phycol 23:543-597

Hou X, Hansen JH, Bjerre AB (2015) Integrated bioethanol and protein production from brown seaweed Laminaria digitata. Bioresour Technol 197:310-317

Hurd CL, Harrison PJ, Bischof K, Lobban CS (2014) Seaweed ecology and physiology, second edn. Cambridge University Press, Cambrige

Islam MS (2005) Nitrogen and phosphorus budget in coastal and marine cage aquaculture and impacts of effluent loading on ecosystem: review and analysis towards model development. Mar Pollut Bull 50:48-61

Jansen HM, Strand Ø, Strohmeier T, Krogness C, Verdegem M, Smaal A (2011) Seasonal variability in nutrient regeneration by mussel Mytilus edulis rope culture in oligotrophic systems. Mar Ecol Prog Ser 431:137-149

Jansen HM, Broch OJ, Bannister R, Cranford P, Handå A, Husa V, Jiang Z, Strohmeier T, Strand Ø (2018) Spatio-temporal dynamics in the dissolved nutrient waste plume from Norwegian salmon cage aquaculture. Aquac Environ Interact 10:385-399

Jeffrey SW, Humphrey GF (1975) New spectrophotometric equations for determining chlorophylls $a, b, c_{1}$ and $c_{2}$ in higher plants, algae and natural phytoplankton. Biochem Physiol Pflanz 167:191-194

Kang YH, Park SR, Oak JH, Shin JA, Chung IK (2009) Physiological responses of Porphyra yezoensis Ueda (Bangiales, Rhodophyta) exposed to high ammonium effluent in a seaweed-based integrated aquaculture system. J Fish Sci Technol 12:70-77

Keuls M (1952) The use of the "studentized range" in connection with an analysis of variance. Euphytica 1:112-122

Kim JK, Yarish C, Hwang EK, Park M, Kim Y (2017) Seaweed aquaculture: cultivation technologies, challenges and its ecosystem services. Algae 32:1-13

Kim JK, Kraemer G, Yarish C (2019) Evaluation of the metal content of farm grown Gracilaria tikvahiae and Saccharina latissima from Long Island Sound and New York Estuaries. Algal Res 40:101484

Korbee N, Huovinen P, Figueroa FL, Aguilera J, Karsten U (2005) Availability of ammonium influences photosynthesis and the accumulation of mycosporine-like amino acids in two Porphyra species (Bangiales, Rhodophyta). Mar Biol 146:645-654

Lazzari R, Baldisserotto B (2008) Nitrogen and phosphorus waste in fish farming. Bol Inst Pesca 34:591-600

Liu H, Fang J, Zhu J, Dong S, Wang F, Liang X, Zhang J, Lian Y, Wang L, Jiang W (2004) Study on limiting nutrients and phytoplankton at long-line-culture areas in Laizhou Bay and Sanggou Bay, northeastern China. Aquatic Conservation: Marine and Freshwater Ecosystems 14 (6):551-574

Lubsch A, Timmermans KR (2019) Uptake kinetics and storage capacity of dissolved inorganic phosphorus and corresponding dissolved inorganic nitrate uptake in Saccharina latissima and Laminaria digitata (Phaeophyceae). J Phycol 55:637-650

Marinho GS, Holdt SL, Birkeland MJ, Angelidaki I (2015a) Commercial cultivation and bioremediation potential of sugar kelp, Saccharina latissima, in Danish waters. J Appl Phycol 27:1963-1973

Marinho GS, Holdt SL, Jacobsen C, Angelidaki I (2015b) Lipids and composition of fatty acids of Saccharina latissima cultivated yearround in integrated multi-trophic aquaculture. Mar Drugs 13:43574374

Mata L, Silva J, Schuenhoff A, Santos R (2006) The effects of light and temperature on the photosynthesis of the Asparagopsis armata tetrasporophyte (Falkenbergia rufolanosa), cultivated in tanks. Aquaculture 252:12-19

Negishi T, Rai H, Hayatsu H (1997) Antigenotoxicity activity of natural chlorophylls. Mutat Res Fundam Mol Mech Mutagen 376:97-100

Nielsen MM, Krause-Jensen D, Olesen B, Thinggaard R, Christensen PB, Bruhn A (2014) Growth dynamics of Saccharina latissima (Laminariales, Phaeophyceae) in Aarhus Bay, Denmark, and along the species' distribution range. Mar Biol 161:2011-2022

Park M, Shin SK, Do YH, Yarish C, Kim YK (2018) Application of open water integrated multi-trophic aquaculture to intensive monoculture: a review of the current status and challenges in Korea. Aquaculture 497:174-183

Parke M (1948) Studies on British Laminariaceae. I. Growth in Laminaria saccharina (L.). J Mar Biol Assoc U K 27:651-709

Parsons TR, Maita Y, Lalli CM (1984) Determination of chlorophylls and total carotenoids: spectrophotometric method. In: A manual of chemical \& biological methods for seawater analysis. Pergamon, London pp 101-104

Peteiro C, Freire Ó (2013) Biomass yield and morphological features of the seaweed Saccharina latissima cultivated at two different sites in a coastal bay in the Atlantic coast of Spain. J Appl Phycol 25: 205213

Phillips JC, Hurd CL (2003) Nitrogen ecophysiology of intertidal seaweeds from New Zealand: $\mathrm{N}$ uptake, storage and utilisation in relation to shore position and season. Mar Ecol Prog Ser 264:31-48 
Platt T, Gallegos CL, Harrison WG (1981) Photoinhibition of photosynthesis in natural assemblages of marine phytoplankton. J Mar Res 38:687-701

Pradeepkiran JA (2019) Aquaculture role in global food security with nutritional value: a review. Transl Anim Sci 3:903-910

Price C, Black KD, Hargrave BT, Morris JA (2015) Marine cage culture and the environment: effects on water quality and primary production. Aquac Environ Interact 6:151-174

Ramnani P, Chitarrari R, Tuohy K, Grant J, Hotchkiss S, Philp K, Campbell R, Gill C, Rowland I (2012) Invitro fermentation and prebiotic potential of novel low molecular weight polysaccharides derived from agar and alginate seaweeds. Anaerobe 18:1-6

Reid G, Robinson S, Chopin T, et al (2007) Recent developments and challenges for open-water, Integrated Multi-Trophic Aquaculture (IMTA) in the Bay of Fundy, Canada. Proceedings of the Canadian Freshwater Symposium - Aquaculture Canada 2007. AAC Special Publication 13:43-47

Reid GK, Chopin T, Robinson SMC, Azevedo P, Quinton M, Belyea E (2013) Weight ratios of the kelps, Alaria esculenta and Saccharina latissima, required to sequester dissolved inorganic nutrients and supply oxygen for Atlantic salmon, Salmo salar, in Integrated Multi-Trophic Aquaculture systems. Aquaculture 408-409:34-46

Riisgård HU, Larsen PS, Pleissner D (2014) Allometric equations for maximum filtration rate in blue mussels Mytilus edulis and importance of condition index. Helgol Mar Res 68:193-198

Roleda MY, Hurd CL (2019) Seaweed nutrient physiology: application of concepts to aquaculture and bioremediation. Phycologia 58:552562

Rößner Y (2013) Integrated multi-trophic aquaculture of mussels (Mytilus edulis) and seaweed (Saccharina latissima) in the Western Baltic Sea. (Doctoral dissertation, Christian-Albrechts Universität Kiel). 103

Rousvoal S, Groisillier A, Dittami SM, Michel G, Boyen C, Tonon T (2011) Mannitol-1-phosphate dehydrogenase activity in Ectocarpus siliculosus, a key role for mannitol synthesis in brown algae. Planta 233:261-273

Sanderson JC, Cromey CJ, Dring MJ, Kelly MS (2008) Distribution of nutrients for seaweed cultivation around salmon cages at farm sites in north-west Scotland. Aquaculture 278:60-68

Sanderson JC, Dring MJ, Davidson K, Kelly MS (2012) Culture, yield and bioremediation potential of Palmaria palmata (Linnaeus) Weber \& Mohr and Saccharina latissima (Linnaeus) C.E. Lane, C. Mayes, Druehl \& G.W. Saunders adjacent to fish farm cages in northwest Scotland. Aquaculture 354-355:128-135

Shi H, Zheng W, Zhang X, Zhu M, Ding D (2013) Ecological-economic assessment of monoculture and integrated multi-trophic aquaculture in Sanggou Bay of China. Aquaculture 410-411:172-178
Silsbe, Greg M, Malkin, Sairah Y (2015) Phytotools: phytoplankton production tools. 1-21

Sterner R, Elser J (2002) Ecological stoichiometry: the biology of elements from molecules to the biosphere. Princeton University Press, Princeton

Stévant P, Marfaing H, Rustad T, Sandbakken I, Fleurence J, Chapman A (2017) Nutritional value of the kelps Alaria esculenta and Saccharina latissima and effects of short-term storage on biomass quality. J Appl Phycol 29:2417-2426

Subasinghe R, Soto D, Jia J (2009) Global aquaculture and its role in sustainable development. Rev Aquac 1:2-9

Takaichi S (2011) Carotenoids in algae: distributions, biosyntheses and functions. Mar Drugs 9:1101-1118

Troell M, Rönnbäck P, Halling C, Kautsk N, Buschmann A (1999) Ecological engineering in aquaculture: use of seaweeds for removing nutrients from intensive mariculture. J Appl Phycol 11:89-97

Troell M, Joyce A, Chopin T, Neori A, Buschmann AH, Fang J-G (2009) Ecological engineering in aquaculture-potential for integrated multitrophic aquaculture (IMTA) in marine offshore systems. Aquaculture 297:1-9

Turpin DH (1991) Effects of inorganic N availability on algal photosynthesis and carbon metabolism. J Phycol 27:14-20

Verhaeghe EF, Fraysse A, Guerquin-Kern J-L, Wu T-D, Devès G, Mioskowski C, Leblanc C, Ortega R, Ambroise Y, Potin P (2008) Microchemical imaging of iodine distribution in the brown alga Laminaria digitata suggests a new mechanism for its accumulation. J Biol Inorg Chem 13:257-269

Vilg JV, Nylund GM, Werner T, Qvirist L, Mayers JJ, Pavia H, Undeland I, Albers E (2015) Seasonal and spatial variation in biochemical composition of Saccharina latissima during a potential harvesting season for Western Sweden. Bot Mar 58:435-447

Wan AHL, Davies SJ, Soler-Vila A, Fitzgerald R, Johnson MP (2019) Macroalgae as a sustainable aquafeed ingredient. Rev Aquac 11: 458-492

Wang Y, Xu D, Fan X, Zhang X, Ye N, Wang W, Mao Y, Mou S, Cao S (2013) Variation of photosynthetic performance, nutrient uptake, and elemental composition of different generations and different thallus parts of Saccharina japonica. J Appl Phycol 25:631-637

Wiencke C, Bischof K (2012) Seaweed biology. Ecological studies, 219. Springer, Berlin

Publisher's note Springer Nature remains neutral with regard to jurisdictional claims in published maps and institutional affiliations. 